\title{
Spinal cord stimulation for neuropathic pain: current perspectives
}

\author{
This article was published in the following Dove Press journal: \\ Journal of Pain Research \\ 18 November 2014 \\ Number of times this article has been viewed
}

\author{
Tilman Wolter \\ Interdisciplinary Pain Centre, \\ University Hospital Freiburg, \\ Freiburg, Germany
}

Correspondence: Tilman Wolter Interdisziplinäres Schmerzzentrum, Universitätsklinikum Freiburg, Breisacherstr 64, 79106 Freiburg Email tilman.wolter@uniklinik-freiburg.de
Abstract: Neuropathic pain constitutes a significant portion of chronic pain. Patients with neuropathic pain are usually more heavily burdened than patients with nociceptive pain. They suffer more often from insomnia, anxiety, and depression. Moreover, analgesic medication often has an insufficient effect on neuropathic pain. Spinal cord stimulation constitutes a therapy alternative that, to date, remains underused. In the last 10 to 15 years, it has undergone constant technical advancement. This review gives an overview of the present practice of spinal cord stimulation for chronic neuropathic pain and current developments such as high-frequency stimulation and peripheral nerve field stimulation.

Keywords: spinal cord stimulation, neuropathic pain, neurostimulation

\section{Introduction}

Neuropathic pain constitutes a significant portion of chronic pain. The International Association for the Study of Pain defines neuropathic pain as pain caused by a lesion or disease of the somatosensory nervous system. Patients with neuropathic pain usually are more heavily burdened than patients with nociceptive pain and suffer more often from insomnia, anxiety, and depression. ${ }^{1}$ Moreover, analgetic medication often has an insufficient effect on neuropathic pain. ${ }^{2}$

Spinal cord stimulation (SCS) constitutes a therapy alternative that, to date, remains underused. ${ }^{3,4}$ It was described for the first time in 1967 and has become a standard therapy in many hospitals since the middle of the 1980s. Nonetheless, there is still a significant underuse of this treatment. In the last 10-15 years, SCS has undergone constant technical advancement. Stimulation patterns can now be adjusted according to the patient's needs, thus increasing the efficacy of stimulation.

SCS for the treatment of pain must be seen in the general context of neuromodulative therapies. Neuromodulation has undergone rapid development in the last few years. Today, neurostimulation systems are used not only in the therapy of chronic pain but also in a multitude of different disorders, such as epilepsy, psychiatric diseases, and movement disorders, as well as gastrointestinal and urological diseases. This review gives an overview of the present practice of SCS for chronic neuropathic pain and current developments in the field.

\section{Outline of the history of SCS and its uses}

The development of SCS was one of the consequences of the gate control theory of Melzack and Wall. ${ }^{5}$ They stated that external and internal pain stimuli are recorded 
by pain receptors in the skin, muscles, joints, and internal organs and switched to the second neuron of the pain pathway within the dorsal horn of the spinal cord. Here, many peripheral neurons converge to a single neuron termed the wide dynamic range neuron. According to their theory, activation of myelinated $A \beta$ fibers inhibits pain transmission and is enhanced by activation of thinly myelinated $\mathrm{A} \delta$ fibers and unmyelinated $\mathrm{C}$ fibers. ${ }^{5}$

Shealy et al employed SCS in 1967 for the first time in an animal model, using a technique that they termed dorsal column stimulation at that time. They showed that dorsal column stimulation, as well as stimulation of the anterior spinocerebellar tract, inhibited paw withdrawal after painful stimuli in cats. ${ }^{6}$ In the same year, they treated a patient who suffered from intractable pain resulting from a progressive-state inoperable bronchial carcinoma. Electrode implantation was performed over a thoracic laminectomy at the level TH 2/3. After starting the stimulation, pain was drastically reduced and analgetic medication could be stopped. The patient died after 6 days from a previously undetected bacterial endocarditis. ${ }^{7}$ In 1970, Shealy et al published a series of six patients with various diagnoses who had been treated with SCS; three of them had a very good outcome. ${ }^{8}$

Nashold and Friedman published the first larger study on SCS in 1972. In this study, patients with neuropathic pain responded better to stimulation than patients with nociceptive pain such as bone pain, joint pain, and discal pain. ${ }^{9}$ The same year, a two-step procedure with percutaneous testing of the electrode before final implantation of the impulse generator was proposed by Hosobuchi et al. ${ }^{10}$ A study of 50 patients published in 1974 showed that SCS led to better results in phantom pain than in peripheral nerve lesions. ${ }^{11}$ Before 1980, intra- or subdural electrodes were often employed, ${ }^{12}$ sometimes leading to grave complications such as intraspinal bleeding ${ }^{13}$ or spinal cord damage. ${ }^{14}$ Therefore, great caution is required in comparing the treatment data from that time with those of our time.

\section{Mechanisms of action}

The first explanation of the effects of SCS according to the gate control theory was that the nociceptive signal in the dorsal horn would be inhibited by antidromic activation of collateral fibers of the dorsal columns. This explanation later turned out to be only partially true. According to this explanation, acute nociceptive pain would be inhibited most effectively by SCS, which in fact is not the case. In addition, the pain-free interval after cessation of stimulation cannot be explained in that way. Apparently, there is also an orthodromic stimulation, which becomes manifest in the paresthesia felt by the patient under stimulation. Supraspinal centers are also involved in SCS effects. ${ }^{15}$ At the time the gate control theory was first described, there was only a little knowledge about supraspinal control of pain transmission, and SCS was thought to act at the segmental level. ${ }^{16}$

In animal models, a couple of possible mechanisms of action have been described. Overexcitability of wide dynamic range (WDR) neurons in the dorsal horn can at least partially be overcome by SCS. ${ }^{17}$ This seems to be related to an increased basal release of glutamate and to a dysfunction of the $\gamma$-amino-butyric acid (GABA) system. SCS counteracts this mechanism by increased GABA release. However, GABA release was only observed in animals that also had pain relief effected by SCS. ${ }^{18}$ Moreover, SCS led to a decreased extracellular glutamate concentration in the dorsal horn. ${ }^{19}$ Here, activation of the $\mathrm{GABA}_{\mathrm{B}}$ receptor seems to play a crucial role. ${ }^{19-21}$ Cholinergic transmitter systems are also involved in SCS effects. Release of acetylcholine was observed under SCS and later attributed to activation of the M4 muscarine receptor. ${ }^{22}$ Moreover, low doses of muscarine receptor agonists led to amplification of the SCS effects in rats, ${ }^{23}$ and it was shown that serotonergic pain-modulating descending pathways were involved in this effect. ${ }^{24}$

Moreover, supraspinal centers are also engaged in the effect of SCS. Here, in particular, a dorsal columnbrainstem-spinal loop is of importance. ${ }^{25-27}$ Barchini et al recently addressed the question of the relative proportions of supraspinal and segmental mechanisms in SCS effects. They studied the effect of SCS on neuropathic pain after lesioning the dorsal columns and stimulating rostral and caudal to the lesion under the influence of different receptor antagonists. They found that segmental as well as supraspinal mechanisms contribute to the effects of SCS and that stimulation rostral and caudal to the lesion leads to activation of different synaptic circuits and transmitter systems. ${ }^{16}$

The question of how stimulation of the spinal ganglia and SCS differ clinically and electrophysiologically was studied by Guan et $\mathrm{al}^{28}$ by means of single-cell electrodes in WDR neurons. They found that SCS inhibited wind-up in the WDR neurons, whereas stimulation of the spinal ganglia did not. The effect of SCS continued, at least partially, for about $30-45$ minutes after cessation of the stimulation. ${ }^{28}$

\section{Patient selection/screening, including psychological}

SCS can have diverging clinical effects in different patients. It has been known for many years that some patients do 
not profit from SCS, but others do. Therefore, a two-step procedure with a test phase before implantation of the impulse generator (IPG) has become routine in most hospitals since the 1970s. It has become apparent that about 17\%-20\% of the patients have a negative trial result ${ }^{29}$ and do not proceed to IPG implantation, even when the test electrode has the optimal position and the paraesthesia coverage of the painful region is complete. Moreover, SCS effects diminish over time after IPG implantation in some patients. The extent of decrease of SCS effect over time is reported variously in the literature. Some studies state that the effect has decreased $25 \%-50 \%$ after 2 years, ${ }^{30}$ but others only see a slight loss of efficacy over time. ${ }^{31}$ Often technical factors such as electrode problems (dislocation, breakage) have been cited to explain the loss of efficiency. However, psychological factors also come into account with regard to both the loss of efficacy over time and a negative trial result.

Several guidelines recommend that psychological testing should be performed before SCS implant. The first aim of this testing is to rule out major psychiatric diseases such as major depression, psychosis, or substance abuse. There is a vast consensus that patients with these diagnoses should not be subjected to SCS testing. However, it remains to be determined whether there are also psychological factors below the level of severe pathology, which can negatively influence SCS efficacy. Regarding this question, the literature remains somewhat inconclusive; regarding the long-term efficiency, there are studies that find a negative correlation between the level of depression and SCS efficacy, ${ }^{32,33}$ whereas others do not. ${ }^{30,33}$

In contrast, the level of depression remains one of the functional items that can show remarkable improvements after SCS implantation. Thus, even if SCS efficacy might be slightly lower in patients with mild depression, IPG implantation might be justified because apart from pain relief, depression can also improve under SCS. ${ }^{31}$

\section{Pre- and postimplant advice to patients}

Preoperatively, the indication should be considered cautiously, taking the prior conservative medical physiotherapeutic and psychotherapeutic approaches into account. Differential diagnosis also requires determining the proportions of nociceptive and neuropathic pain; for instance, by means of diagnostic nerve root blocks. SCS should be considered when the radicular (neuropathic) part of the pain outweighs the nociceptive portion (Figure 1).

Some guidelines, moreover, claim interdisciplinary decision-making before testing SCS. At least a psychological examination should be carried out before SCS implantation in any case. The psychological examination should not only contribute to decision-making about whether or not to implant the electrode, but should also prepare the patient for the postoperative course and render it easier for the patient to deal with having an implantable device.

Electrode implantation usually is performed under local anaesthesia, using percutaneous-type electrodes, which can be inserted under fluoroscopic guidance. First, the spinal canal is punctured with a Touhy needle. Once the spinal canal is reached, intraspinal localization of the needle tip is ensured by means of a saline probe, a technique that can be strongly recommended to ensure the safety of the procedure and to prevent cerebrospinal fluid leaks. Then, the electrode is advanced to the desired level. In the case of leg pain, the usual electrode position is TH10-12 (Figure 2). In thoracic pain (such as postherpetic neuralgia), the electrode position depends on the level of the pathology, and in brachial pain, final electrode position is at level C3-C6 (Figure 3). Once the electrode is in the desired position, intraoperative test simulation is performed and the patient is asked to state where he feels the stimulation-induced paresthesia. At this stage, it is most important to obtain full paresthesia coverage of the painful area. Sometimes the electrode position must be changed before the optimal paraesthesia is achieved.

The patient then proceeds to a test phase, which usually lasts about 6-12 days. Some hospitals also prefer testing under domestic circumstances. Mostly, however, testing is performed in the hospital. The patient is asked to document his or her pain scores during the test phase. The decision whether or not to implant an IPG is dependent on whether or not more than $50 \%$ pain reduction is obtained, whether quality of life and moods are improved, whether analgetic medication can be reduced, and whether the patient wants the implant.

After implantation of the IPG, reprogramming of the device often is needed one or more times. Patients should be informed that slight changes in the SCS-induced paresthesia can occur and that these can be relieved by reprogramming the device. Patients often ask whether they should avoid physical activities to avoid electrode dislocation. In our experience, the risk for electrode dislocation is highest in the first few weeks after implantation, so we would not recommend heavy lifting or intense bending of the spine in this stage. After implantation of the IPG, the analgetic medication should also be reconsidered and possibly stopped. The patient can also better determine over time which simulation pattern, intermittent or continuous, is most suitable in his situation. ${ }^{34}$ 


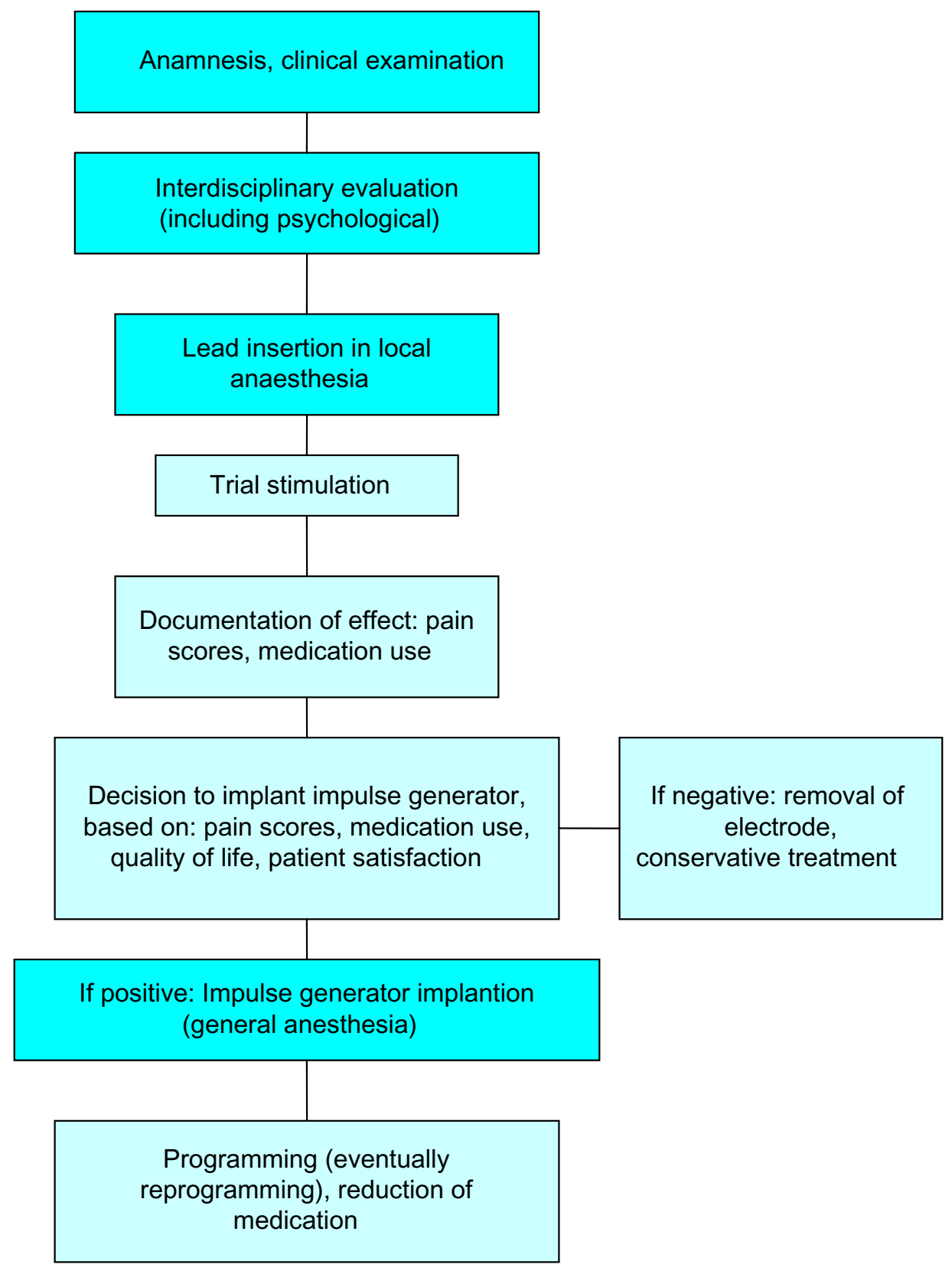

Figure I Flow chart of spinal cord stimulation procedure.

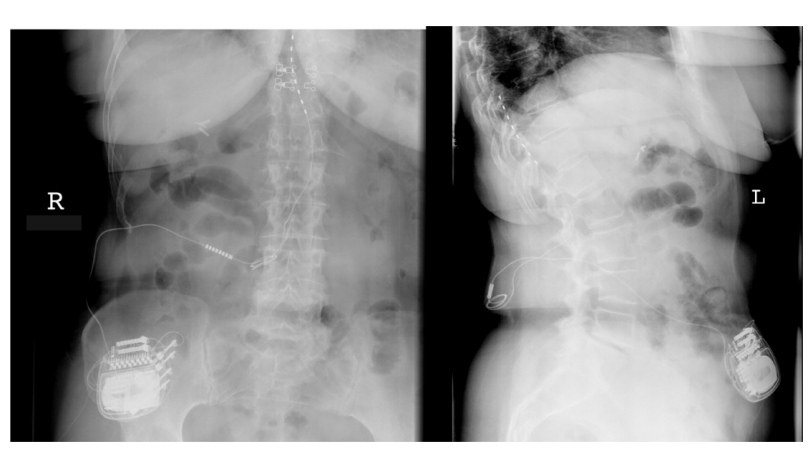

Figure 2 Anteroposterior and lateral view of a thoracolumbar spinal cord stimulation placement; the 8-pole lead (octrode) is positioned at level THI0-12, and the impulse generator is placed abdominally subcutaneously.

Abbreviations: $R$, right; $L$, left.

\section{Current technological developments}

\section{Burst stimulation}

One new development in SCS refers to the order and frequency of impulses. De Ridder et $\mathrm{al}^{35}$ published a series of 12 patients who had been treated by means of a "burst stimulation". This pattern of stimulation consists in socalled "bursts" of 5 impulses of $1 \mathrm{~ms}$ duration followed by a $1 \mathrm{~ms}$ interval, applied at a frequency of $500 \mathrm{~Hz}$. These 5 -impulse "bursts" are applied at $40 \mathrm{~Hz}$. Under this stimulation pattern, pain was strongly relieved compared with using conventional stimulation. Moreover, no stimulation-induced 


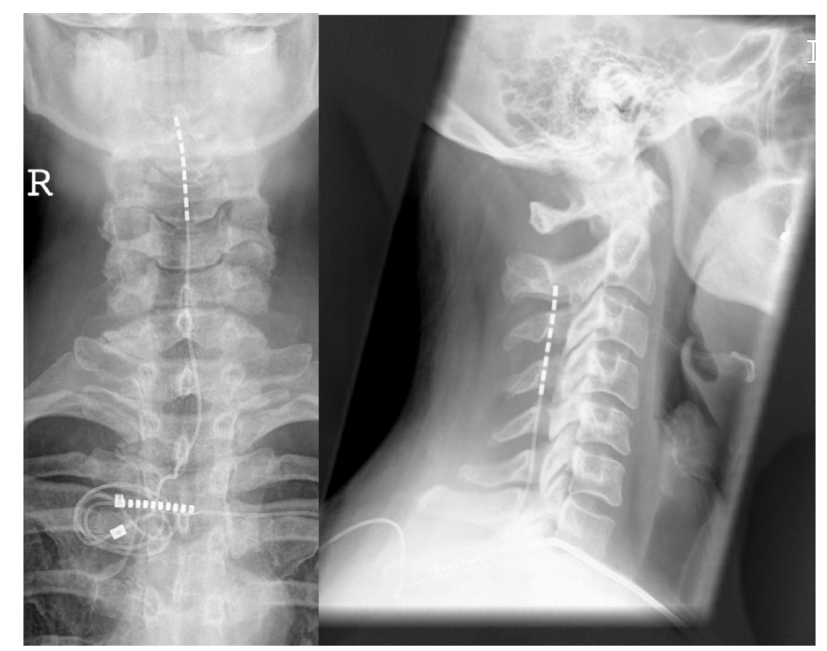

Figure 3 Anteroposterior and lateral view of a cervical spinal cord stimulation placement; the 8-pole lead (octrode) is positioned at level C3-5, and the spinal canal is entered at level TH2/3.

Abbreviation: R, right.

paresthesia was necessary to obtain a pain-relieving effect. Furthermore, unlike "conventional" SCS, not only leg pain but also back pain was relieved. ${ }^{35,36}$

\section{High-frequency stimulation}

Recently, a prospective multicenter study on high-frequency SCS (continuous stimulation with $10 \mathrm{kHz}$ ) showed favorable results. ${ }^{37}$ In this new technique, two octrodes are implanted in a staggered manner at level TH8 down to TH12. It has been observed that not only radicular leg pain but also back pain can be treated in this way. Eighty-two patients were treated in the study. An IPG was implanted in 72 patients. The mean intensity of back pain decreased from 8.2 to 2.7 on the visual analog scale and the mean intensity of the leg pain decreased from 5.4 to 1.4. The results also remained stable after 24 months. ${ }^{38}$ One peculiarity of this stimulation technique is that no paresthesia is perceived by the patient. The effectivity of high-frequency stimulation was explained by desensitization of hyperactive WDR neurons and with control of the wind-up phenomenon of WDR neurons. However, no experimental evidence for this assumption was provided. ${ }^{37}$ Moreover, a randomized study that compared a $5 \mathrm{kHz}$ stimulation with a sham stimulation in a blinded manner did not find significant differences between the two stimulation techniques. ${ }^{39}$

At the present stage, it is probably too early to draw final conclusions on the pain-relieving efficiency of highfrequency stimulation. However, as long as there is no clear neurophysiological hypothesis explaining the intense effect and the paresthesia-free pain relief, some reservation toward this new method might be indicated.

\section{Position-adaptive SCS}

The intensity of the SCS-induced paresthesia is dependent on body position. ${ }^{40-42}$ Under equal technical settings of the stimulator, the paresthesia is perceived more intensely in the supine position than in an upright position. Therefore, up to now, patients had to correct changes in stimulation intensity (ie, while standing up) by means of a handheld programming device. This position dependency of the stimulation is not caused by a dislocation of the electrode. In fact, it is based on the variable thickness of the cerebrospinal fluid layer around the spinal cord. Holsheimer et al ${ }^{43}$ pointed out that the position of the spinal cord within the spinal canal exhibited considerable interindividual differences. By means of a computer model, they calculated the expected thresholds for stimulation on the basis of anatomical and radiological data. The calculated data corresponded to the thresholds measured in individual patients. ${ }^{43}$ Likewise, Abejon and Feler ${ }^{44}$ found that the impedance of the electrode is not dependent on the body position. Thus, changes in body position do not interfere with changes in the electrical conductivity of the electrode and the directly adjacent tissues. ${ }^{44,45}$

Recently, new position-adaptive stimulation devices have been introduced. These devices are able to detect whether the patient is lying down or standing. The stimulation intensity is then automatically fitted to previously set values. With this technique, there is no longer any need for the patient to adjust the stimulation intensity after changing his position.

A study with 15 patients showed that patients with automatic sensor-driven stimulation were significantly more satisfied than with manually adapted stimulation. ${ }^{46} \mathrm{~A}$ recent multicenter study with 79 patients showed functional improvements; in particular, enhanced comfort during position changes, increased physical activity, and improved sleep. ${ }^{47}$

\section{Novel peripheral neurostimulation techniques}

Two new developments of neurostimulation are addressed here that actually do not constitute a type of SCS, as the peripheral nerves or the dorsal root ganglion are stimulated rather than the spinal cord. However, these techniques share most of the indications and use much of the same hardware. Therefore, they should be mentioned in the context of SCS.

\section{Peripheral nerve field stimulation}

Stimulation of a single peripheral nerve has been employed for more than 30 years in pain treatment. ${ }^{48}$ With this technique, the affected peripheral nerve (ie, N. ulnaris) is exposed and an electrode (ie, a cuff-electrode) is placed directly adjacent to the nerve. Alternatively, a percutaneous-type electrode can be inserted under the epineurium. ${ }^{49}$ 
Peripheral nerve field stimulation (PNFS) is a different method. Here the electrode is placed subcutaneously, with no direct relation to a particular peripheral nerve. One of the first applications of this method was occipital nerve stimulation (ONS) for chronic migraine ${ }^{50}$ or chronic cluster headache. ${ }^{51-54}$ Here, however, there are different opinions about whether ONS is a peripheral nerve stimulation or a PNFS. In fact, the electrode is mostly placed adjacent to the occipital nerve in ONS, but as this is not done under visual control, this ONS is probably a form of PNFS rather than peripheral nerve stimulation. ${ }^{55}$

PNFS in a way closes a therapeutic gap in neuromodulative pain treatment, as it can possibly reach the trunk more effectively than SCS. First publications on PNFS dealt with chronic abdominal pain. ${ }^{56,57}$ Later, studies concerning chronic thoracic pain, ${ }^{58,59}$ chronic low back pain, ${ }^{60-63}$ failed back surgery syndrome (FBSS), ${ }^{64,65}$ and sacroiliac joint pain ${ }^{66}$ also were published.

PNFS has been described in a couple of case reports, ${ }^{58,59,67}$ smaller cases series, ${ }^{56,62,65}$ and some studies with higher case numbers. ${ }^{61,64,68}$ A retrospective multicentre study on 111 patients with chronic low back pain, FBSS, cervical pain, postherpetic neuralgia, tension headache, and some patients with trigeminal neuralgia or thoracic pain showed that the relatively best pain relief was obtained in patients with thoracic back pain, whereas the least pain relief was seen in patients with tension headache. Pain scores in total decreased from 8.2 without stimulation to 4.0 with stimulation. The mean medication use was significantly reduced. ${ }^{69} \mathrm{~A}$ recent prospective multicenter study on 118 patients of PFNS on chronic low back pain showed similar results. ${ }^{70}$

Interestingly, pain relief by TENS does not seem to be a predictor for the success of PFNS, ${ }^{71}$ and pain relief elicited by PNFS seems to be stronger than in TENS. ${ }^{69} \mathrm{~A}$ so-called "hybrid simulation", combining SCS and PFNS, has also been proposed for various pain syndromes. . $1,62,65,67,72-74^{-1}$

A randomized study on PFNS showed that the stimulation under standard settings is significantly more effective than at subthreshold intensity or low frequency. ${ }^{75}$

The advantages of PNFS are that it is less invasive and that it offers the opportunity to treat the pain syndromes that cannot be treated with SCS. Some pain syndromes, such as postherpetic neuralgia, can be treated by both PFNS and SCS, and it remains to be determined which of the two techniques offers the higher efficiency. The comparison of the effects of SCS and TENS, as a peripheral stimulation, on evoked potentials showed that the SCS effect was nearly twice as strong as that of TENS. ${ }^{76}$

\section{Dorsal root ganglion stimulation}

In this technique, the electrode is placed directly adjacent to the spinal ganglion. With one electrode, paresthesia is only achieved within a single dermatome. Greater pain areas can be covered with the use of more than one electrode. The implantation technique is more challenging than that of SCS. A pilot study on 10 patients showed a mean pain relief of $70 \%$ in the first days after implantation. Energy consumption with this technique seems to be significantly less compared with SCS. ${ }^{77}$ A recent multicenter study on 32 patients with a 6-month follow-up showed a mean pain relief of 58\%. As expected, mean pain relief was strongest in the feet and weakest in the low back. ${ }^{78} \mathrm{~A}$ series of eight patients with complex regional pain syndrome (CRPS) showed a decrease of mean pain scores of $62 \%$ under dorsal root ganglion stimulation. ${ }^{79}$ Dorsal root ganglion stimulation can be considered particularly in monoradicular pain syndromes or pain syndromes affecting a very limited number of dermatomes.

\section{Indications}

In general, SCS is indicated in refractory neuropathic pain (Table 1). Early experiences have suggested that SCS is less effective in nociceptive pain. Nonetheless, in some cases it might be difficult to differentiate between the neuropathic and the nociceptive components of pain, and an SCS trial can be justified even if there are also nociceptive components in the pain syndrome. The most frequent and best studied indication is radicular pain secondary to lumbar disc surgery (FBSS). According to a recent review, FBSS evolves in approximately $30 \%$ of patients after lumbar disc surgery. ${ }^{80}$ Two randomized controlled trials and numerous retrospective studies have been published for FBSS. In a crossover design, North et al ${ }^{81}$ studied 50 patients with FBSS who had either SCS or a revision operation. Forty-five persons were followed for 3 years. Nine of 19 patients with SCS and three of 26 patients with the reoperation had more than $50 \%$ pain relief. In the SCS group, the crossover rate was lower than in the reoperation group (5/24 versus 14/26) ${ }^{81}$ A study on 100 patients with FBSS and predominantly neuropathic leg pain was conducted by Kumar et al. ${ }^{82}$ They randomized the patients into two groups; one group had conventional analgetic therapy alone and the other group had conventional analgetic plus SCS. The earliest time for a crossover was 6 months. At that time, $48 \%$ of the patients who had been treated with SCS had more than $50 \%$ pain relief, whereas this was the case in the conservative treatment group in only $9 \%$ of the patients. Again, the crossover rate was significantly lower in the SCS group than in the conservative group (5/50 versus $32 / 50){ }^{82}$ 
Table I Overview of indications and contraindications for spinal cord stimulation

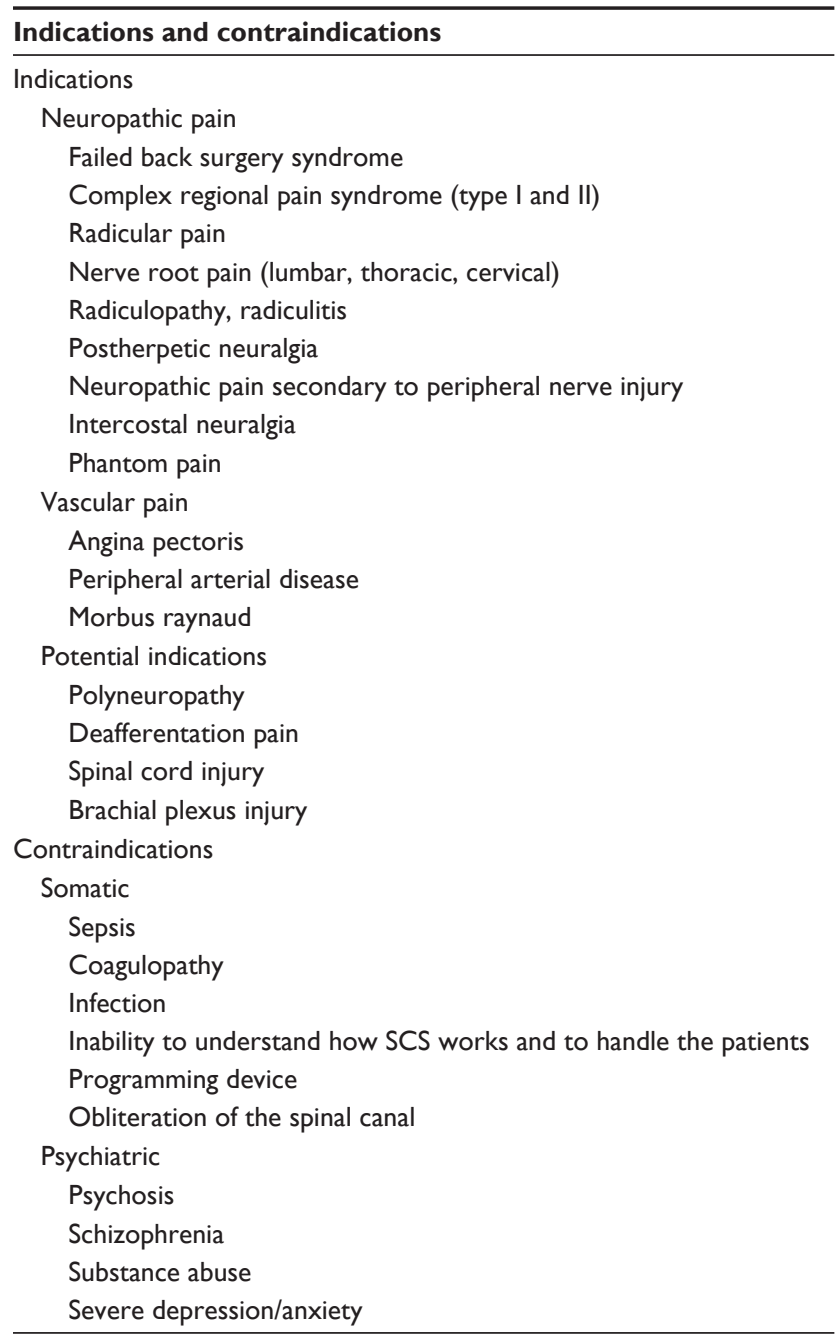

Abbreviation: SCS, spinal cord stimulation.

Several guidelines recommend a trial of SCS in FBSS. A systematic review found class IIb evidence for efficacy of SCS in FBSS. ${ }^{83}$

Another good and well-studied indication for SCS is CRPS (CRPS I and II). In this potentially devastating neuroorthopedic pain syndrome the use of SCS has been studied in several observational studies and one randomized controlled trial. In this study, the effectivity of SCS combined with a 6-month physiotherapeutic treatment protocol was compared with a physiotherapeutic treatment protocol alone. Thirty-six patients were included in the SCS group, whereas 18 patients had solely physiotherapeutic treatment. Test stimulation was successful in 24 of the 36 patients. Patients in the SCS group had a mean pain relief of 2.4 points (on an 11-point scale), whereas patients with solely physiotherapeutic treatment had pain relief of 0.2 points. These differences were statistically significant and remained stable after 1 and 2 years. ${ }^{84} \mathrm{After} 3$ and
5 years, however, significant differences in the treatment groups were no longer seen. In these studies, as in the primary study, an intention-to-treat analysis was carried out that included the 12 patients with the negative trial in the SCS group. Moreover, four patients in the control group had received an SCS system. ${ }^{85,86}$ Interestingly, a study by Harke et a ${ }^{87}$ had a kind of internal control. This internal control, in which the stimulator was switched off for 45 minutes, was performed every 3 months during the 35-month follow-up. Pain scores for depth pain and allodynia during these inactivity tests were 7.1/10 and 4.0/10, respectively. Under stimulation, these scores decreased to $1.7 / 10$ and $0.03 / 10$, respectively. ${ }^{87}$ in addition to these studies, several case series regarding the use of SCS for the treatment of CRPS have been published. A meta-analysis showed that $67 \%$ of the patients experienced pain relief of more than $50 \%{ }^{88}$

SCS has also been successfully employed in a number of neuropathic pain syndromes. Excellent results have been achieved in the treatment of postherpetic neuralgia. In $23 / 28$ patients, pain relief from a median $9 / 10$ on the visual analog scale to $1 / 10$ was achieved. Complete pain relief was observed in 23 of 28 patients (82\%) after 3-66 months. ${ }^{89}$ Moreover, postherpetic neuralgia has been studied in a number of larger studies with miscellaneous indications. ${ }^{90-92}$ A meta-analysis showed a success rate of $82 \% .{ }^{93}$ Interestingly, SCS has also been proposed as a short-term therapy for subacute herpes zoster or beginning postherpetic neuralgia. Here, a 14-day short-term therapy with an externalized electrode led to complete and lasting pain relief in some patients. ${ }^{94,95}$

One indication for SCS that is not yet general practice is diabetic polyneuropathy. In 1996, a case series was published in which 8 of 10 patients tested were treated with SCS. Mean pain scores decreased in these patients from 7.7/10 to $2.3 / 10$. However, pallhypesthesia and electrophysiological tests remained unchanged. ${ }^{96}$ A systematic review of SCS for diabetic polyneuropathy lists three prospective case series and one retrospective cohort study. At 1-year follow-up, $63 \%$ of the patients had more than $50 \%$ pain reduction. In addition, analgetic medication could be stopped in $60 \%$ of the patients. ${ }^{97}$ Recently, long-term effects for SCS for diabetic polyneuropathy were shown over a follow-up of 3 years. ${ }^{98}$

Successful pain treatment with SCS has been described in a single case report in a vast variety of neuropathic pain syndromes such as syringomyelia, ${ }^{99}$ post-thoracotomy neuralgia, ${ }^{100}$ recurrent neuroma, ${ }^{101}$ tethered cord syndrome, ${ }^{102}$ meralgia paresthetica, ${ }^{103}$ or even multiple sclerosis. ${ }^{104}$ Favorable outcomes have also been reported in mixed pain syndromes regarding shoulder pain ${ }^{105}$ and knee pain. ${ }^{106}$ 
An overview of randomized controlled studies is given in Table 2. ${ }^{36,39,46,47,75,81,82,84,85,107-111}$

\section{Safety}

SCS can be considered a safe technique. The probability of sustaining permanent damage caused by an SCS trial is extremely low. The puncture of the spinal canal comprises the inherent risk of spinal bleeding and permanent neurological deficit; however, the literature lists only six reported cases of neurological deficits resulting from damage of the spinal cord. In 2010, Smith et al reported a series of four patients with paraparesis occurring after a spinal cord stimulator trial. ${ }^{112}$ Two of these patients had spinal bleeding, one patient had spinal cord injury, and in one patient a preexisting thoracic disc herniation was encountered. To rule out thoracic disc herniation or spinal stenosis, the authors advocated magnetic resonance imaging (MRI) before SCS lead insertion. In the same article, the authors quoted two additional cases of paraparesis secondary to SCS

Table 2 Overview of randomized studies for SCS (and PNFS)

\begin{tabular}{|c|c|c|c|c|c|c|}
\hline Title/author & Year & Diagnosis & Condition & Design & $\mathbf{n}$ & Result \\
\hline \multicolumn{7}{|c|}{ Conventional SCS } \\
\hline $\begin{array}{l}\text { PROCESS, } \\
\text { Kumar } \\
\text { et } \mathrm{al}^{82,107}\end{array}$ & 2005 & $\begin{array}{l}\text { Failed back surgery } \\
\text { syndrome }\end{array}$ & $\begin{array}{l}\text { SCS plus CMM vs CMM } \\
\text { alone }\end{array}$ & $\begin{array}{l}\text { Randomized prospective, } \\
\text { multicenter }\end{array}$ & 100 & $\begin{array}{l}48 \% \text { of the SCS patients had more } \\
\text { than } 50 \% \text { pain relief compared with } \\
9 \% \text { with CMM, cross-over-rate } \\
\text { was significantly lower in the SCS } \\
\text { group than in the CMM group } \\
(5 / 50 \text { vs } 32 / 50)\end{array}$ \\
\hline $\begin{array}{l}\text { North } \\
\text { et } \mathrm{a}^{81,108,109}\end{array}$ & 1994 & $\begin{array}{l}\text { Failed back surgery } \\
\text { syndrome }\end{array}$ & $\begin{array}{l}\text { SCS plus CMM vs } \\
\text { reoperation plus CMM }\end{array}$ & $\begin{array}{l}\text { Randomized prospective, } \\
\text { multicenter }\end{array}$ & 60 & $\begin{array}{l}9 / 19 \text { patients with SCS and } \\
3 / 26 \text { patients with reoperation } \\
\text { had more than } 50 \% \text { pain relief; in } \\
\text { the SCS group, the crossover rate } \\
\text { was lower than in the reoperation } \\
\text { group }(5 / 24 \text { vs } 14 / 26)\end{array}$ \\
\hline $\begin{array}{l}\text { Kemler } \\
\text { et } \mathrm{al}^{84,85,110}\end{array}$ & 2000 & $\begin{array}{l}\text { Complex regional pain } \\
\text { syndrome type I }\end{array}$ & $\begin{array}{l}\text { SCS plus physical therapy } \\
\text { vs physical therapy }\end{array}$ & $\begin{array}{l}\text { Randomized prospective, } \\
\text { multicenter }\end{array}$ & 54 & $\begin{array}{l}24 / 36 \text { patients had a successful test } \\
\text { and were implanted, mean change } \\
\text { in pain at } 6 \text { months; } 2.4 \text { VAS with } \\
\text { SCS vs; } 0.2 \text { VAS without SCS }\end{array}$ \\
\hline \multicolumn{7}{|c|}{ Subthreshold stimulation } \\
\hline Wolter et al" & | 2011 & Neuropathic pain & $\begin{array}{l}\text { SCS vs subthreshold SCS } \\
\text { vs no stimulation }\end{array}$ & $\begin{array}{l}\text { Randomized prospective, } \\
\text { crossover design }\end{array}$ & 10 & $\begin{array}{l}\text { SCS: mean VAS, } 3.6 \text {; subthreshold: } \\
\text { 5.6; no stimulation: } 6.4 \text {; differences } \\
\text { significant }\end{array}$ \\
\hline \multicolumn{7}{|c|}{ Adaptive stimulation } \\
\hline Schultz et $\mathrm{al}^{47}$ & 2012 & $\begin{array}{l}\text { Neuropathic back and } \\
\text { leg pain }\end{array}$ & $\begin{array}{l}\text { Conventional SCS vs } \\
\text { position adaptive SCS }\end{array}$ & $\begin{array}{l}\text { Randomized prospective, } \\
\text { multicenter crossover } \\
\text { design }\end{array}$ & 79 & $\begin{array}{l}\text { Improved convenience of adaptive } \\
\text { stimulation compared with using } \\
\text { manual programming adjustment } \\
\text { alone }\end{array}$ \\
\hline Schade et $\mathrm{al}^{46}$ & 2011 & $\begin{array}{l}\text { Neuropathic back and } \\
\text { leg pain }\end{array}$ & $\begin{array}{l}\text { Conventional SCS vs } \\
\text { position adaptive SCS }\end{array}$ & $\begin{array}{l}\text { Randomized prospective, } \\
\text { multicenter crossover } \\
\text { design }\end{array}$ & 15 & $\begin{array}{l}\text { Improved convenience and overall } \\
\text { satisfaction of adaptive stimulation }\end{array}$ \\
\hline \multicolumn{7}{|c|}{ High-frequency stimulation } \\
\hline $\begin{array}{l}\text { Perruchoud } \\
\text { et } \mathrm{al}^{39}\end{array}$ & 2013 & $\begin{array}{l}\text { Neuropathic back and } \\
\text { leg pain }\end{array}$ & HF SCS vs SCS vs sham & $\begin{array}{l}\text { Randomized prospective, } \\
\text { crossover design }\end{array}$ & 33 & $\begin{array}{l}\text { Switched from conventional SCS to } \\
5 \mathrm{kHz} \text { SCS or to sham, VAS levels } \\
\text { remained stable; authors concluded } \\
\text { that HF SCS was equivalent to sham }\end{array}$ \\
\hline \multicolumn{7}{|l|}{ Burst stimulation } \\
\hline $\begin{array}{l}\text { De Ridder } \\
\text { et } \mathrm{al}^{36}\end{array}$ & 2013 & $\begin{array}{l}\text { Neuropathic back and } \\
\text { leg pain }\end{array}$ & Burst vs tonic vs placebo & $\begin{array}{l}\text { Randomized prospective, } \\
\text { crossover design }\end{array}$ & 15 & $\begin{array}{l}\text { Burst stimulation improved back, } \\
\text { limb, and general pain by } 51 \%, 53 \% \text {, } \\
\text { and } 55 \% \text { and tonic stimulation by } \\
30 \%, 52 \% \text {, and } 31 \%\end{array}$ \\
\hline \multicolumn{7}{|l|}{ PNFS } \\
\hline $\begin{array}{l}\text { McRoberts } \\
\text { et } \mathrm{al}^{75}\end{array}$ & 2013 & $\begin{array}{l}\text { Localized, chronic, } \\
\text { intractable back pain }\end{array}$ & PNFS & $\begin{array}{l}\text { Randomized prospective, } \\
\text { multicenter crossover } \\
\text { design }\end{array}$ & 44 & $\begin{array}{l}23 \text { patients responded to } \\
\text { stimulation ( }<50 \% \text { pain reduction) } \\
\text { and received impulse generators }\end{array}$ \\
\hline
\end{tabular}

Abbreviations: SCS, spinal cord stimulation; PNFS, peripheral nerve field stimulation; CMM, conventional medical management; HF SCS, high-frequency SCS; VAS, visual analog scale; vs, versus. 
lead insertion: one case of dural puncture and intramedullary lead placement ${ }^{113}$ and another case of needle penetration in the cervical cord ${ }^{114}$ However, neurological deficit developing in the course of time, as a consequence of scarring, ${ }^{115-117}$ of an epidural mass, ${ }^{118}$ or of a foreign body reaction ${ }^{119}$ has also been reported in case reports. Given the fact that several hundred thousand SCS devices have been implanted worldwide since its advent, even admitting that neurological deficits after SCS might be underreported, this hints at a low probability of permanent neurologic deficit to SCS electrode implantation.

Infection can occur after SCS implantation. The incidence is reported between $3.4 \%{ }^{92}$ and $6 \% .{ }^{120}$ Usually, cases of infection have an uneventful benign course when the electrodes are removed and antibiotic therapy is initiated.

The probability of unscheduled additional revision operations caused by hardware problems, such as lead dislocation or lead breakage, is apparently high. A systematic review of SCS for FBSS or chronic back and leg pain found that $43 \%$ of the patients had one or more complications with SCS. Most of these were lead problems (lead dislocation). Infections were encountered in $6 \%$ of the patients and cerebral spinal fluid leaks in $7 \% .{ }^{120}$ A monocentric study on 707 patients found no patient with permanent neurologic deficit. However, hardware failures in this series occurred in $38 \%$ of the patients $(22.6 \%$ lead migration, $9.5 \%$ lead connection failure, and $6 \%$ lead breakage). ${ }^{121}$ Another large study on hardware failure modes found a significantly higher revision rate in cervical than in thoracolumbar SCS systems. Again, lead migration was the most frequent cause of repeat surgery $^{122}$ (Table 3).

The use of paddle leads that have to be implanted surgically via laminotomy has been advocated for patients with a history of lead migration. A recent study showed that the initial complication rate was higher with paddle leads compared with percutaneous leads, but the longer-term reoperation rate was significantly lower. ${ }^{123}$

Table 3 Possible complications of spinal cord stimulation

\begin{tabular}{l}
\hline Complication \\
\hline Hardware-related \\
Lead migration \\
Lead breakage \\
Connection failure \\
Battery depletion \\
Unwanted paresthesia \\
Pain at the impulse generator site \\
Not hardware-related \\
Hematoma, seroma infection \\
Cerebrospinal fluid loss \\
Neurological deficit \\
\hline
\end{tabular}

Interaction of SCS with diathermy, cardiac pacemakers, ultrasound, or MRI is possible and can lead to unwanted paresthesia or dysfunction of the system. In particular, MRI may exert forces on the implanted material and therefore may induce the risk of, for example, intraspinal bleeding. Last year a MRI-compatible SCS system was newly introduced. However, a recent study showed that as with conventional SCS systems using an adapted protocol, a MRI (1.5 T) can be performed safely. ${ }^{124}$

\section{Long-term outcomes and place in therapy}

Outcomes of SCS therapy have considerably improved over the course of the last 30 years. Although in the 1970s about $40 \%$ of the patients achieved pain relief of more than $50 \%$, this percentage in recent studies is more than $70 \%$. Proper patient selection and meticulous preoperative diagnostics, including psychological assessment, are crucial for the success of the method. Moreover, more knowledge regarding promising indications has been gathered over the course of the years. SCS therapy today is not necessarily seen as a therapy of last resort, but as an effective possibility to overcome pain that would otherwise be difficult to treat. Unsuccessful conventional medical management is regarded as a criterion in favor of an SCS trial. However, most of the guidelines do not state whether or not opioids, particularly strong opioids, should be employed. Today, many pain physicians probably would not insist on a prior therapeutic attempt with highly potent opioids, and SCS would be ranked in the therapeutic order between weak and strong opioids. At any rate, the disadvantages of long-term opioid therapy ${ }^{125}$ should be weighed against those of SCS therapy. SCS can certainly be used together with analgetic medications, but in an optimal setting, SCS can make pain medication redundant. Often, however, patients continue to take analgetic medications. For instance, in a study on 60 consecutive patients, $16 \%$ of the patients took no analgetics at all after SCS implantation, whereas more than half of the patients took two or more different analgetics. ${ }^{31}$

Another important point is the duration of conservative therapy before SCS implantation. Kumar et al observed an inverse correlation between the long-term success rate and the time interval between the onset of the chronic pain syndrome and SCS implantation. They noted that the success rate in patients who received their SCS system within the first 2 years of their pain syndrome was $85 \%$, whereas the success rate was $9 \%$ in patients with a more than 15 -year history of chronic pain. ${ }^{126,127}$ As a consequence, an SCS trial should be performed within the first 2 years 
after onset of pain. In contrast, also less invasive therapies should have been tried before an SCS trial, so realistically, SCS will rarely be applied earlier than 6-12 months from the onset of pain. Anyway, also a recent review concluded that SCS for CRPS "should be considered earlier than last resort therapy". ${ }^{128}$

\section{Conclusion}

SCS is an effective treatment option for neuropathic pain. Technical advancement of SCS has led to improvement in stimulation patterns adapted to the patients' needs. SCS for neuropathic pain is still underused. Careful preoperative diagnosis and proper patient selection is most important for the success of the methods.

\section{Disclosure}

The author reports no conflicts of interest in this work.

\section{References}

1. Freynhagen R, Baron R, Gockel U, Tölle TR. painDETECT: a new screening questionnaire to identify neuropathic components in patients with back pain. Curr Med Res Opin. 2006;22(10): 1911-1920.

2. Finnerup NB, Otto M, McQuay HJ, Jensen TS, Sindrup SH. Algorithm for neuropathic pain treatment: an evidence based proposal. Pain. 2005;118(3):289-305.

3. Kumar K, Rizvi S. Cost-effectiveness of spinal cord stimulation therapy in management of chronic pain. Pain Med. 2013;14(11):1631-1649.

4. Vyawahare B, Hallas N, Brookes M, Taylor RS, Eldabe S. Impact of the National Institute for Health and Care Excellence (NICE) guidance on medical technology uptake: analysis of the uptake of spinal cord stimulation in England 2008-2012. BMJ Open. 2014; 4(1):e004182.

5. Melzack R, Wall PD. Pain mechanisms: a new theory. Science. 1965;150(3699):971-979.

6. Shealy CN, Taslitz N, Mortimer JT, Becker DP. Electrical inhibition of pain: experimental evaluation. Anesth Analg. 1967;46(3): 299-305.

7. Shealy CN, Mortimer JT, Reswick JB. Electrical inhibition of pain by stimulation of the dorsal columns: preliminary clinical report. Anesth Analg. 1967;46(4):489-491.

8. Shealy CN, Mortimer JT, Hagfors NR. Dorsal column electroanalgesia. J Neurosurg. 1970;32(5):560-564.

9. Nashold BS Jr, Friedman H. Dorsal column stimulation for control of pain. Preliminary report on 30 patients. J Neurosurg. 1972;36(5): 590-597.

10. Hosobuchi Y, Adams JE, Weinstein PR. Preliminary percutaneous dorsal column stimulation prior to permanent implantation. Technical note. J Neurosurg. 1972;37(2):242-245.

11. Krainick JU, Thoden U. Experience with dorsal column stimulation (DCS) in the operative treatment of chronic intractable pain. J Neurosurg Sci. 1974;18(3):187-189.

12. Tronnier V. [Neuromodulation for chronic pain conditions]. Bremen: Uni Med Verlag; 2003. German.

13. Grillo PJ, Yu HC, Patterson RH Jr. Delayed intraspinal hemorrhage after dorsal column stimulation for pain. Arch Neurol. 1974;30(1): $105-106$.

14. Taub A, Collins WF, Venes J. Partial, reversible, functional spinal cord transection. A complication of dorsal column stimulation for the relief of pain. Arch Neurol. 1974;30(1):107-108.
15. Nashold B, Somjen G, Friedman H. Paresthesias and EEG potentials evoked by stimulation of the dorsal funiculi in man. Exp Neurol. 1972;36(2):273-287.

16. Barchini J, Tchachaghian S, Shamaa F, et al. Spinal segmental and supraspinal mechanisms underlying the pain-relieving effects of spinal cord stimulation: an experimental study in a rat model of neuropathy. Neuroscience. 2012;215:196-208.

17. Yakhnitsa V, Linderoth B, Meyerson BA. Spinal cord stimulation attenuates dorsal horn neuronal hyperexcitability in a rat model of mononeuropathy. Pain. 1999;79(2-3):223-233.

18. Stiller CO, Cui JG, O'Connor WT, Brodin E, Meyerson BA, Linderoth B. Release of gamma-aminobutyric acid in the dorsal horn and suppression of tactile allodynia by spinal cord stimulation in mononeuropathic rats. Neurosurgery. 1996;39(2):367-374.

19. Cui JG, O'Connor WT, Ungerstedt U, Linderoth B, Meyerson BA. Spinal cord stimulation attenuates augmented dorsal horn release of excitatory amino acids in mononeuropathy via a GABAergic mechanism. Pain. 1997;73(1):87-95.

20. Linderoth B, Meyerson BA. Spinal cord stimulation: exploration of the physiological basis of a widely used therapy. Anesthesiology. 2010;113(6):1265-1267.

21. Cui JG, Linderoth B, Meyerson BA. Effects of spinal cord stimulation on touch-evoked allodynia involve GABAergic mechanisms. An experimental study in the mononeuropathic rat. Pain. 1996;66(2-3): 287-295.

22. Schechtmann G, Song Z, Ultenius C, Meyerson BA, Linderoth B. Cholinergic mechanisms involved in the pain relieving effect of spinal cord stimulation in a model of neuropathy. Pain. 2008;139(1):136-145.

23. Song Z, Meyerson BA, Linderoth B. Muscarinic receptor activation potentiates the effect of spinal cord stimulation on pain-related behavior in rats with mononeuropathy. Neurosci Lett. 2008;436(1):7-12.

24. Song Z, Ultenius C, Meyerson BA, Linderoth B. Pain relief by spinal cord stimulation involves serotonergic mechanisms: an experimental study in a rat model of mononeuropathy. Pain. 2009;147(1-3):241-248.

25. Saadé NE, Tabet MS, Soueidan SA, Bitar M, Atweh SF, Jabbur SJ. Supraspinal modulation of nociception in awake rats by stimulation of the dorsal column nuclei. Brain Res. 1986;369(1-2):307-310.

26. Saadé NE, Atweh SF, Privat A, Jabbur SJ. Inhibitory effects from various types of dorsal column and raphe magnus stimulations on nociceptive withdrawal flexion reflexes. Brain Res. 1999;846(1):72-86.

27. El-Khoury C, Hawwa N, Baliki M, Atweh SF, Jabbur SJ, Saadé NE. Attenuation of neuropathic pain by segmental and supraspinal activation of the dorsal column system in awake rats. Neuroscience. 2002;112(3):541-553.

28. Guan Y, Wacnik PW, Yang F, et al. Spinal cord stimulation-induced analgesia: electrical stimulation of dorsal column and dorsal roots attenuates dorsal horn neuronal excitability in neuropathic rats. Anesthesiology. 2010;113(6):1392-1405.

29. Kumar K, Wilson JR. Factors affecting spinal cord stimulation outcome in chronic benign pain with suggestions to improve success rate. Acta Neurochir Suppl. 2007;97(Pt 1):91-99.

30. Sparkes E, Raphael JH, Duarte RV, LeMarchand K, Jackson C, Ashford RL. A systematic literature review of psychological characteristics as determinants of outcome for spinal cord stimulation therapy. Pain. 2010;150(2):284-289.

31. Wolter T, Fauler I, Kieselbach K. The impact of psychological factors on outcomes for spinal cord stimulation: an analysis with long-term follow-up. Pain Physician. 2013;16(3):265-275.

32. Brandwin MA, Kewman DG. MMPI indicators of treatment response to spinal epidural stimulation in patients with chronic pain and patients with movement disorders. Psychol Rep. 1982;51(3 Pt 2):1059-1064.

33. Burchiel KJ, Anderson VC, Brown FD, et al. Prospective, multicenter study of spinal cord stimulation for relief of chronic back and extremity pain. Spine. 1996;21(23):2786-2794.

34. Wolter T, Winkelmüller M. Continuous versus intermittent spinal cord stimulation: an analysis of factors influencing clinical efficacy. Neuromodulation. 2012;15(1):13-19, discussion 20. 
35. De Ridder D, Vanneste S, Plazier M, van der Loo E, Menovsky T. Burst spinal cord stimulation: toward paresthesia-free pain suppression. Neurosurgery. 2010;66(5):986-990.

36. De Ridder D, Plazier M, Kamerling N, Menovsky T, Vanneste S. Burst spinal cord stimulation for limb and back pain. World Neurosurg. 2013;80(5):642-649.

37. Van Buyten JP, Al-Kaisy A, Smet I, Palmisani S, Smith T. Highfrequency spinal cord stimulation for the treatment of chronic back pain patients: results of a prospective multicenter European clinical study. Neuromodulation. 2013;16(1):59-65.

38. Al-Kaisy A, Van Buyten JP, Smet I, Palmisani S, Pang D, Smith T. Sustained effectiveness of $10 \mathrm{kHz}$ high-frequency spinal cord stimulation for patients with chronic, low back pain: 24-month results of a prospective multicenter study. Pain Med. 2014;15(3):347-354.

39. Perruchoud C, Eldabe S, Batterham AM, et al. Analgesic efficacy of high-frequency spinal cord stimulation: a randomized double-blind placebo-controlled study. Neuromodulation. 2013;16(4):363-369, discussion 369.

40. Barolat G, Zeme S, Ketcik B. Multifactorial analysis of epidural spinal cord stimulation. Stereotact Funct Neurosurg. 1991;56(2):77-103.

41. Cameron T, Alo KM. Effects of posture on stimulation parameters in spinal cord stimulation. Neuromodulation. 1998;1(4):177-183.

42. Olin JC, Kidd DH, North RB. Postural changes in spinal cord stimulation perceptual thresholds. Neuromodulation. 1998;1(4):171-175.

43. Holsheimer J, Barolat G, Struijk JJ, He J. Significance of the spinal cord position in spinal cord stimulation. Acta Neurochir Suppl (Wien). 1995;64:119-124.

44. Abejon D, Feler CA. Is impedance a parameter to be taken into account in spinal cord stimulation? Pain Physician. 2007;10(4):533-540.

45. Holsheimer J, den Boer JA, Struijk JJ, Rozeboom AR. MR assessment of the normal position of the spinal cord in the spinal canal. AJNR Am J Neuroradiol. 1994;15(5):951-959.

46. Schade CM, Schultz DM, Tamayo N, Iyer S, Panken E. Automatic adaptation of neurostimulation therapy in response to changes in patient position: results of the Posture Responsive Spinal Cord Stimulation (PRS) Research Study. Pain Physician. 2011;14(5):407-417.

47. Schultz DM, Webster L, Kosek P, Dar U, Tan Y, Sun M. Sensordriven position-adaptive spinal cord stimulation for chronic pain. Pain Physician. 2012;15(1):1-12.

48. Law JD, Swett J, Kirsch WM. Retrospective analysis of 22 patients with chronic pain treated by peripheral nerve stimulation. J Neurosurg. 1980;52(4):482485.

49. Buschmann D, Oppel F. [Peripheral nerve stimulation for pain relief in CRPS II and phantom-limb pain]. Schmerz. 1999;13(2): 113-120. German.

50. Weiner RL, Reed KL. Peripheral neurostimulation for control of intractable occipital neuralgia. Neuromodulation. 1999;2(3):217-221.

51. Burns B, Watkins L, Goadsby PJ. Treatment of medically intractable cluster headache by occipital nerve stimulation: long-term follow-up of eight patients. Lancet. 2007;369(9567):1099-1106.

52. Burns B, Watkins L, Goadsby PJ. Treatment of intractable chronic cluster headache by occipital nerve stimulation in 14 patients. Neurology. 2009;72(4):341-345

53. Magis D, Allena M, Bolla M, De Pasqua V, Remacle JM, Schoenen J. Occipital nerve stimulation for drug-resistant chronic cluster headache: a prospective pilot study. Lancet Neurol. 2007;6(4):314-321.

54. Magis D, Gerardy PY, Remacle JM, Schoenen J. Sustained effectiveness of occipital nerve stimulation in drug-resistant chronic cluster headache. Headache. 2011;51(8):1191-1201.

55. Tronnier V, Rasche D. [Subcutaneous peripheral stimulation of the greater occipital nerve for the treatment of chronic headache syndromes]. Schmerz. 2010;24(5):441-448. German.

56. Paicius RM, Bernstein CA, Lempert-Cohen C. Peripheral nerve field stimulation in chronic abdominal pain. Pain Physician. 2006;9(3): 261-266.

57. Barolat G. Peripheral subcutaneous stimulation for intractable abdominal pain. Prog Neurol Surg. 2011;24:70-76.
58. McJunkin TL, Berardoni N, Lynch PJ, Amrani J. An innovative case report detailing the successful treatment of post-thoracotomy syndrome with peripheral nerve field stimulation. Neuromodulation. 2010;13(4):311-314.

59. Goyal GN, Gupta D, Jain R, Kumar S, Mishra S, Bhatnagar S. Peripheral nerve field stimulation for intractable post-thoracotomy scar pain not relieved by conventional treatment. Pain Pract. 2010;10(4): 366-369.

60. Paicius RM, Bernstein CA, Lempert-Cohen C. Peripheral Nerve Field Stimulation for the Treatment of Chronic Low Back Pain: Preliminary Results of Long-Term Follow-up: A Case Series. Neuromodulation. 2007;10(3):279-290.

61. Bernstein CA, Paicius RM, Barkow SH, Lempert-Cohen C. Spinal cord stimulation in conjunction with peripheral nerve field stimulation for the treatment of low back and leg pain: a case series. Neuromodulation. 2008;11(2):116-123.

62. Hamm-Faber TE, Aukes HA, de Loos F, Gültuna I. Subcutaneous stimulation as an additional therapy to spinal cord stimulation for the treatment of lower limb pain and/or back pain: a feasibility study. Neuromodulation. 2012;15(2):108-116.

63. Burgher AH, Huntoon MA, Turley TW, Doust MW, Stearns LJ. Subcutaneous peripheral nerve stimulation with inter-lead stimulation for axial neck and low back pain: case series and review of the literature. Neuromodulation. 2012;15(2):100-106, discussion 106-107.

64. Yakovlev AE, Resch BE, Yakovleva VE. Peripheral nerve field stimulation in the treatment of postlaminectomy syndrome after multilevel spinal surgeries. Neuromodulation. 2011;14(6):534-538, discussion 538.

65. Reverberi C, Dario A, Barolat G. Spinal cord stimulation (SCS) in conjunction with peripheral nerve field stimulation (PNfS) for the treatment of complex pain in failed back surgery syndrome (FBSS). Neuromodulation. 2013;16(1):78-82.

66. Patil AA, Otto D, Raikar S. Peripheral nerve field stimulation for sacroiliac joint pain. Neuromodulation. 2014;17(1):98-101.

67. Lepski G, Vahedi P, Tatagiba MS, Morgalla M. Combined spinal cord and peripheral nerve field stimulation for persistent post-herniorrhaphy pain. Neuromodulation. 2013;16(1):84-88, discussion 88-89.

68. Verrills P, Vivian D, Mitchell B, Barnard A. Peripheral nerve field stimulation for chronic pain: 100 cases and review of the literature. Pain Med. 2011;12(9):1395-1405.

69. Sator-Katzenschlager S, Fiala K, Kress HG, et al. Subcutaneous target stimulation (STS) in chronic noncancer pain: a nationwide retrospective study. Pain Pract. 2010;10(4):279-286.

70. Kloimstein H, Likar R, Kern M, et al. Peripheral nerve field stimulation (PNFS) in chronic low back pain: a prospective multicenter study. Neuromodulation. 2014;17(2):180-187.

71. Goroszeniuk T, Kothari S, Hamann W. Subcutaneous neuromodulating implant targeted at the site of pain. Reg Anesth Pain Med. 2006;31(2):168-171.

72. Falco FJ, Berger J, Vrable A, Onyewu O, Zhu J. Cross talk: a new method for peripheral nerve stimulation. An observational report with cadaveric verification. Pain Physician. 2009;12(6):965-983.

73. Mironer YE, Hutcheson JK, Satterthwaite JR, LaTourette PC. Prospective, two-part study of the interaction between spinal cord stimulation and peripheral nerve field stimulation in patients with low back pain: development of a new spinal-peripheral neurostimulation method. Neuromodulation. 2011;14(2):151-154, discussion 155.

74. Lipov EG. 'Hybrid neurostimulator': simultaneous use of spinal cord and peripheral nerve field stimulation to treat low back and leg pain. Prog Neurol Surg. 2011;24:147-155.

75. McRoberts WP, Wolkowitz R, Meyer DJ, et al. Peripheral nerve field stimulation for the management of localized chronic intractable back pain: results from a randomized controlled study. Neuromodulation. 2013;16(6):565-574, discussion 574-575. 
76. Wolter T, Kieselbach K, Sircar R, Gierthmuehlen M. Spinal cord stimulation inhibits cortical somatosensory evoked potentials significantly stronger than transcutaneous electrical nerve stimulation. Pain Physician. 2013;16(4):405-414.

77. Deer TR, Grigsby E, Weiner RL, Wilcosky B, Kramer JM. A prospective study of dorsal root ganglion stimulation for the relief of chronic pain. Neuromodulation. 2013;16(1):67-71, discussion 71-72.

78. Liem L, Russo M, Huygen FJ, et al. A multicenter, prospective trial to assess the safety and performance of the spinal modulation dorsal root ganglion neurostimulator system in the treatment of chronic pain. Neuromodulation. 2013;16(5):471-482, discussion 482.

79. Van Buyten JP, Smet I, Liem L, Russo M, Huygen F. Stimulation of Dorsal Root Ganglia for the Management of Complex Regional Pain Syndrome: A Prospective Case Series. Pain Pract. Jan 2014:23.

80. van Buyten JP, Linderoth B. "The failed back surgery syndrome': Definition and therapeutic algorithms - An update." Eur J Pain Suppl. 2010;4(4):273-286.

81. North RB, Kidd DH, Farrokhi F, Piantadosi SA. Spinal cord stimulation versus repeated lumbosacral spine surgery for chronic pain: a randomized, controlled trial. Neurosurgery. 2005;56(1):98-106, discussion 106-107.

82. Kumar K, North R, Taylor R, et al. Spinal Cord Stimulation vs Conventional Medical Management: A Prospective, Randomized, Controlled, Multicenter Study of Patients with Failed Back Surgery Syndrome (PROCESS Study). Neuromodulation. 2005;8(4): 213-218.

83. Frey ME, Manchikanti L, Benyamin RM, Schultz DM, Smith HS, Cohen SP. Spinal cord stimulation for patients with failed back surgery syndrome: a systematic review. Pain Physician. 2009;12(2): 379-397.

84. Kemler MA, De Vet HC, Barendse GA, Van Den Wildenberg FA, Van Kleef M. The effect of spinal cord stimulation in patients with chronic reflex sympathetic dystrophy: two years' follow-up of the randomized controlled trial. Ann Neurol. 2004;55(1):13-18.

85. Kemler MA, de Vet HC, Barendse GA, van den Wildenberg FA, van Kleef M. Spinal cord stimulation for chronic reflex sympathetic dystrophy - five-year follow-up. N Engl J Med. 2006;354(22): 2394-2396.

86. Kemler MA, de Vet HC, Barendse GA, van den Wildenberg FA, van Kleef M. Effect of spinal cord stimulation for chronic complex regional pain syndrome Type I: five-year final follow-up of patients in a randomized controlled trial. J Neurosurg. 2008;108(2):292-298.

87. Harke H, Gretenkort P, Ladleif HU, Rahman S. Spinal cord stimulation in sympathetically maintained complex regional pain syndrome type I with severe disability. A prospective clinical study. Eur J Pain. 2005;9(4):363-373.

88. Taylor RS. Spinal cord stimulation in complex regional pain syndrome and refractory neuropathic back and leg pain/failed back surgery syndrome: results of a systematic review and meta-analysis. J Pain Symptom Manage. 2006;31(4)(Suppl):S13-S19.

89. Harke H, Gretenkort P, Ladleif HU, Koester P, Rahman S. Spinal cord stimulation in postherpetic neuralgia and in acute herpes zoster pain. Anesth Analg. 2002;94(3):694-700. Table of contents.

90. Meglio M, Cioni B, Rossi GF. Spinal cord stimulation in management of chronic pain. A 9-year experience. J Neurosurg. 1989;70(4): 519-524.

91. Broggi G, Servello D, Dones I, Carbone G. Italian multicentric study on pain treatment with epidural spinal cord stimulation. Stereotact Funct Neurosurg. 1994;62(1-4):273-278.

92. Kumar K, Toth C, Nath RK. Spinal cord stimulation for chronic pain in peripheral neuropathy. Surg Neurol. 1996;46(4):363-369.

93. Cameron T. Safety and efficacy of spinal cord stimulation for the treatment of chronic pain: a 20-year literature review. J Neurosurg. 2004;100(Suppl Spine 3):254-267.

94. Moriyama K. Effect of temporary spinal cord stimulation on postherpetic neuralgia in the thoracic nerve area. Neuromodulation. 2009;12(1):39-43.
95. Iseki M, Morita Y, Nakamura Y, Ifuku M, Komatsu S. Efficacy of limited-duration spinal cord stimulation for subacute postherpetic neuralgia. Ann Acad Med Singapore. 2009;38(11):1004-1006.

96. Tesfaye S, Watt J, Benbow SJ, Pang KA, Miles J, MacFarlane IA. Electrical spinal-cord stimulation for painful diabetic peripheral neuropathy. Lancet. 1996;348(9043):1698-1701.

97. Pluijms WA, Slangen R, Joosten EA, et al. Electrical spinal cord stimulation in painful diabetic polyneuropathy, a systematic review on treatment efficacy and safety. Eur J Pain. 2011;15(8): 783-788.

98. Slangen R, Pluijms WA, Faber CG, Dirksen CD, Kessels AG, van Kleef M. Sustained effect of spinal cord stimulation on pain and quality of life in painful diabetic peripheral neuropathy. Br JAnaesth. 2013;111(6):1030-1031.

99. Campos WK, Almeida de Oliveira YS, Ciampi de Andrade D, Teixeira MJ, Fonoff ET. Spinal cord stimulation for the treatment of neuropathic pain related to syringomyelia. Pain Med. 2013;14(5):767-768.

100. Wininger KL, Bester ML, Deshpande KK. Spinal cord stimulation to treat postthoracotomy neuralgia: non-small-cell lung cancer: a case report. Pain Manag Nurs. 2012;13(1):52-59.

101. Messina G, Nazzi V, Sinisi M, Dones I, Pollo B, Franzini A. Spinal cord stimulation for recurrent painful neuromas of the foot. Neurol Sci. 2011;32(4):723-725.

102. Moens M, De Smedt A, D’Haese J, Droogmans S, Chaskis C. Spinal cord stimulation as a treatment for refractory neuropathic pain in tethered cord syndrome: a case report. J Med Case Reports. 2010;4(1):74.

103. Barna SA, Hu MM, Buxo C, Trella J, Cosgrove GR. Spinal cord stimulation for treatment of meralgia paresthetica. Pain Physician. 2005;8(3):315-318.

104. Burkey AR, Abla-Yao S. Successful treatment of central pain in a multiple sclerosis patient with epidural stimulation of the dorsal root entry zone. Pain Med. 2010;11(1):127-132.

105. Williams KA, Babade M, Cohen SP. Spinal cord stimulation for severe degenerative joint disease of the shoulder in a patient with severe chronic obstructive pulmonary disease: a new indication? Anesth Analg. 2010;110(1):220-221.

106. Lowry AM, Simopoulos TT. Spinal cord stimulation for the treatment of chronic knee pain following total knee replacement. Pain Physician. 2010;13(3):251-256.

107. Kumar K, Taylor RS, Jacques L, et al. Spinal cord stimulation versus conventional medical management for neuropathic pain: a multicentre randomised controlled trial in patients with failed back surgery syndrome. Pain. 2007;132(1-2):179-188.

108. North RB, Kidd DH, Lee MS, Piantodosi S. A prospective, randomized study of spinal cord stimulation versus reoperation for failed back surgery syndrome: initial results. Stereotact Funct Neurosurg. 1994;62(1-4):267-272.

109. North RB, Kidd DH, Piantadosi S. Spinal cord stimulation versus reoperation for failed back surgery syndrome: a prospective, randomized study design. Acta Neurochir Suppl (Wien). 1995;64: 106-108.

110. Kemler MA, Barendse GA, van Kleef M, et al. Spinal cord stimulation in patients with chronic reflex sympathetic dystrophy. $N$ Engl J Med. 2000;343(9):618-624.

111. Wolter T, Kiemen A, Porzelius C, Kaube H. Effects of subperception threshold spinal cord stimulation in neuropathic pain: a randomized controlled double-blind crossover study. Eur J Pain. 2012;16(5):648-655.

112. Smith CC, Lin JL, Shokat M, Dosanjh SS, Casthely D. A report of paraparesis following spinal cord stimulator trial, implantation and revision. Pain Physician. 2010;13(4):357-363.

113. Meyer SC, Swartz K, Johnson JP. Quadriparesis and spinal cord stimulation: case report. Spine. 2007;32(19):E565-E568.

114. Barolat G, Peacock W, Staudt L. Pain and spasticity. In: Benzel E, editor. Spine Surgery: Techniques, Complication Avoidance, and Management. Vol 2. 2nd ed. Philadelphia: Elsevier Churchill Livingstone; 2005:1239-1252. 
115. Dam-Hieu P, Magro E, Seizeur R, Simon A, Quinio B. Cervical cord compression due to delayed scarring around epidural electrodes used in spinal cord stimulation. J Neurosurg Spine. 2010;12(4): 409-412.

116. Wada E, Kawai H. Late onset cervical myelopathy secondary to fibrous scar tissue formation around the spinal cord stimulation electrode. Spinal Cord. 2010;48(8):646-648.

117. Cicuendez M, Munarriz PM, Castaño-Leon AM, Paredes I. Dorsal myelopathy secondary to epidural fibrous scar tissue around a spinal cord stimulation electrode. J Neurosurg Spine. 2012;17(6): 598-601.

118. Wloch A, Capelle HH, Saryyeva A, Krauss JK. Cervical myelopathy due to an epidural cervical mass after chronic cervical spinal cord stimulation. Stereotact Funct Neurosurg. 2013;91(4): 265-269.

119. Lennarson PJ, Guillen FT. Spinal cord compression from a foreign body reaction to spinal cord stimulation: a previously unreported complication. Spine. 2010;35(25):E1516-E1519

120. Taylor RS, Van Buyten JP, Buchser E. Spinal cord stimulation for chronic back and leg pain and failed back surgery syndrome: a systematic review and analysis of prognostic factors. Spine (Phila $\mathrm{Pa}$ 1976). 2005;30(1):152-160.

121. Mekhail NA, Mathews M, Nageeb F, Guirguis M, Mekhail MN, Cheng J. Retrospective review of 707 cases of spinal cord stimulation: indications and complications. Pain Pract. 2011;11(2):148-153.

122. Rosenow JM, Stanton-Hicks M, Rezai AR, Henderson JM. Failure modes of spinal cord stimulation hardware. J Neurosurg Spine. 2006;5(3):183-190.
123. Babu R, Hazzard MA, Huang KT, et al. Outcomes of percutaneous and paddle lead implantation for spinal cord stimulation: a comparative analysis of complications, reoperation rates, and health-care costs. Neuromodulation. 2013;16(5):418-426, discussion 426-427.

124. Mutter UM, Bellut D, Porchet F, Schuknecht B. Spinal magnetic resonance imaging with reduced specific absorption rate in patients harbouring a spinal cord stimulation device - A single-centre prospective study analysing safety, tolerability and image quality. Acta Neurochir (Wien). 2013;155(12):2327-2332.

125. Ivanova JI, Birnbaum HG, Yushkina Y, Sorg RA, Reed J, Merchant S. The prevalence and economic impact of prescription opioid-related side effects among patients with chronic noncancer pain. J Opioid Manag. 2013;9(4):239-254.

126. Kumar K, Hunter G, Demeria D. Spinal cord stimulation in treatment of chronic benign pain: challenges in treatment planning and present status, a 22-year experience. Neurosurgery. 2006;58(3):481-496, discussion 481-496.

127. Kumar K, Rizvi S, Nguyen R, Abbas M, Bishop S, Murthy V. Impact of Wait times on Spinal Cord Stimulation Therapy Outcomes. Pain Pract. Epub October 25, 2013.

128. Poree L, Krames E, Pope J, Deer TR, Levy R, Schultz L. Spinal cord stimulation as treatment for complex regional pain syndrome should be considered earlier than last resort therapy. Neuromodulation 2013;16(2):125-141.
Journal of Pain Research

\section{Publish your work in this journal}

The Journal of Pain Research is an international, peer-reviewed, open access, online journal that welcomes laboratory and clinical findings in the fields of pain research and the prevention and management of pain. Original research, reviews, symposium reports, hypothesis formation and commentaries are all considered for publication.

\section{Dovepress}

The manuscript management system is completely online and includes a very quick and fair peer-review system, which is all easy to use. Visit http://www.dovepress.com/testimonials.php to read real quotes from published authors. 